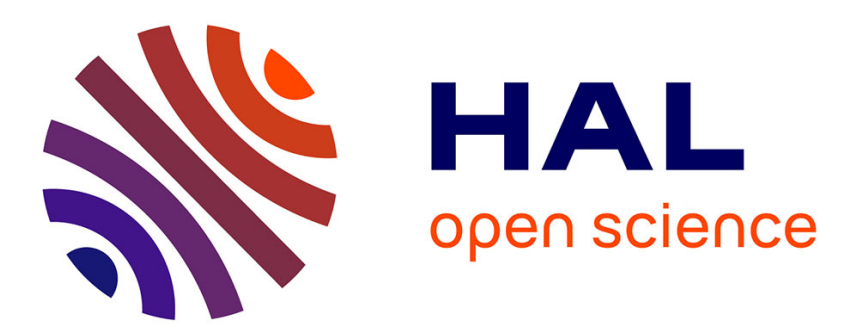

\title{
The effects of macroeconomic stability on foreign trade. An analysis for Spain, 1986-2000
}

\author{
Ana Belén Gracia, Maria Dolores Gadea, José María Serrano
}

\section{To cite this version:}

Ana Belén Gracia, Maria Dolores Gadea, José María Serrano. The effects of macroeconomic stability on foreign trade. An analysis for Spain, 1986-2000. Applied Economics, 2006, 38 (17), pp.2021-2036. $10.1080 / 00036840500427395$. hal-00581898

\section{HAL Id: hal-00581898 https://hal.science/hal-00581898}

Submitted on 1 Apr 2011

HAL is a multi-disciplinary open access archive for the deposit and dissemination of scientific research documents, whether they are published or not. The documents may come from teaching and research institutions in France or abroad, or from public or private research centers.
L'archive ouverte pluridisciplinaire HAL, est destinée au dépôt et à la diffusion de documents scientifiques de niveau recherche, publiés ou non, émanant des établissements d'enseignement et de recherche français ou étrangers, des laboratoires publics ou privés. 


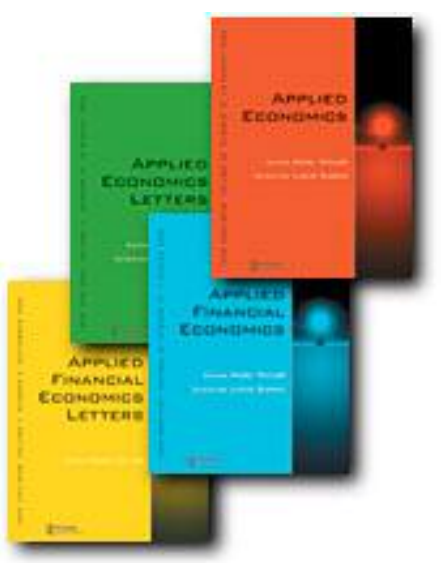

The effects of macroeconomic stability on foreign trade. An analysis for Spain, 1986-2000

\begin{tabular}{|c|c|}
\hline Journal: & Applied Economics \\
\hline Manuscript ID: & APE-04-0244.R1 \\
\hline Journal Selection: & Applied Economics \\
\hline $\begin{array}{r}\text { Date Submitted by the } \\
\text { Author: }\end{array}$ & 13-Apr-2005 \\
\hline JEL Code: & $\begin{array}{l}\text { C22 - Time-Series Models < C2 - Econometric Methods: Single } \\
\text { Equation Models < C - Mathematical and Quantitative Methods, F15 } \\
\text { - Economic Integration < F1 - Trade < F - International Economics, } \\
\text { F36 - Financial Aspects of Economic Integration < F3 - International } \\
\text { Finance < F - International Economics }\end{array}$ \\
\hline Keywords: & $\begin{array}{l}\text { Import function, Export function, Monetary Integration, Sapnish } \\
\text { trade }\end{array}$ \\
\hline
\end{tabular}




\title{
The effects of macroeconomic stability
}

on foreign trade. An analysis for Spain, 1986-2000

\author{
Ana Belén Gracia Andía \\ María Dolores Gadea Rivas \\ José María Serrano Sanz \\ University of Zaragoza
}
ADDRESS: Ana Belén Gracia Andía
Department of Applied Economics
University of Zaragoza
Gran Vía, 2
Zaragoza-50010
Spain
Telephone: 976761812
Fax: 976761840
E-mail: abgracia@.unizar.es




\begin{abstract}
* $^{*}$
Two main factors underlie the rebirth of interest in the study of the influence of the real exchange rate on trade, the reduction of its volatility and the current trend towards price stability. The objective of this paper is to analyse the effects of the process of nominal convergence, required of the European member states for the fulfilment of monetary integration, on foreign trade flows. The case of Spain, which is especially interesting in this context, is studied for the period 1986-2000. The results of estimating the aggregate functions of the export and import of goods shows how macroeconomic stability has altered the behaviour of trade with respect to the two basic determinants -income and prices-, how it has caused a significant structural change in the real exchange rate and, finally, how it has laid the explanatory bases for transactions in the $21^{\text {st }}$ century with the single currency -the euro.
\end{abstract}

JEL Classification: C22, F15, F36

Key Words: import and export functions, monetary integration, Spanish trade.

* The authors wish to acknowledge the useful comments and suggestions of Marcela Sabaté, Antonio Montañés, José Luis Fernández, participants in the seminar of the European Economics and Finance Society (EEFS) Conference held between May 13-16, 2004 in Gdansk (Poland) and the editor of Applied Economics, Mark Taylor. This research has received the financial support of a CICYT (SEC 2003-06106) Project and the SEIM research group (SEC 269-62) Programme. 


\section{Introduction}

European monetary integration has obliged the member states to adopt adjustment policies to fulfil the nominal convergence criteria required by Maastricht. Along with the budgetary constraints on public deficit and debt, there were price requirements, an intense process of inflation control and of foreign exchange stability in the last years. As a consequence of this control over monetary variables, intraeuropean trade flows may have been conditioned by the favourable evolution of prices, one of the two basic determinants of trade. The compulsory macro-economic stability has altered the series of the indexes of real effective exchange rates of the euro countries, especially of those that started out from a more unstable position, and this has possibly caused a change, not only in the evolution of trade, but also in its explanatory bases. In an area that concentrates the majority of its members' trade flows, and in which neither prices nor exchange rates can be used as instruments of economic policy, $21^{\text {st }}$ century trade may have to be explained in function of new variables.

Both the effect of the real exchange rate on trade and the present trend towards price stability are widely debated topics in recent international economic literature ${ }^{1}$. With regard to the first, the influence of the real exchange rate on the trade balance, the debate focuses mainly on whether the volatility of the exchange rate significantly affects trade flows ${ }^{2}$. The second, and predominantly within the European framework of the successful economic and monetary integration, the relevant question is whether a greater nominal stability has been achieved by the member states and whether this has encouraged trade ${ }^{3}$. Furthermore, in this context of greater stability, non-price factors are increasingly important in the determination of trade flows ${ }^{4}$. Against this background, perhaps the main contribution of this article is its macroeconomic treatment of the real exchange rate as a determinant of trade in a more stable framework. 
The case of Spain is special for the analysis of the possible effects of macroeconomic stability on foreign trade because of its significant inflation differential and the intense appreciation of the peseta at the beginning of the nineties. After the European Monetary System (EMS) crisis and the devaluations of 1992 and 1993, Spain reached monetary stability and, in the mid-nineties, began a strict price control that ended with the integration of the peseta into the euro in 1999. The objective of this article is precisely to analyse the possible effects of the nominal convergence achieved in the nineties on Spanish trade. In order to do this, we have estimated the export and import functions_paying special attention to the two fundamental variables -income and relative prices-, especially to the latter due to their singular behaviour throughout the period. Our starting hypothesis is that the macroeconomic stability required by the single currency may have altered the explanatory base of the most recent trade flows and exercised relevant effects on present Spanish commerce.

The article is divided into the following four sections. In the first we describe the methodology, sources and data used in the paper. The second is focused on the estimation of the aggregate import and export goods functions. The third deals with illustrating the effects that the crucial years of nominal convergence have had on commerce. Lastly, the fourth presents the principal conclusions of the work.

\section{Methodology, sources and data}

The idea of structural change has always been present in Economics, given that the phenomena analysed may be subject to shocks of diverse kinds modifying the theoretical relationships. In consequence, diverse econometric techniques have tried to test the statistical significance of these changes and the stability of the estimated parameters 5 . The methodology used in this paper studies the presence, effects and 
position of structural breaks in trade functions, within the framework of the theory of cointegration. Both the exports and imports functions would have the same expression:

$$
c=f(y, p)
$$

where $c$ represents the corresponding trade flow -export or import; $y$ the vector of variables of income; and $p$ that of the relative prices, or other factors of competitiveness. Carrying out the habitual logarithmic transformation, the lineal functional form allows us to estimate the elasticities. The sample period runs from Spain's joining of the European Economic Community (1986) until the adoption of the euro in 1999. The periodicity of the analysis is quarterly, a temporal perspective which allows us, apart from having a larger number of observations, to approximate the short-run dynamics of the net external demand when faced with changes in its principal determinants. All the variables are used without filtering and in logarithms; their description, source and notation are presented in the statistical Appendix.

The first step was to analyse the integration order of the variables used; secondly, the long and short-run relationships were estimated testing for the existence of cointegration; thirdly, we looked for the existence of instability in the parameters, determining the point where the structural break was produced. And finally, the model was re-estimated incorporating the changes detected, allowing them to affect the parameters of the model or the stochastic characteristics of the series affected.

The analysis of the order of integration of all the series used was carried out using the well-known test of Dickey-Fuller (1981), DF, and its extension for quarterly data proposed by Hylleberg, Engel, Granger and Yoo (1999), HEGY. According to the results, the null hypothesis of the existence of the unit root cannot be rejected for any of the series used. As for the frequencies different to zero, only the endogenous variable exports of goods seems to present a seasonal component of a stochastic nature. 
Nevertheless, we have preferred to maintain the gross series, without filtering, because the analysis of the residuals of the cointegration relationship seems to eliminate the problem of seasonality, the series of world income presenting a deterministic seasonal component $^{6}$.

Being integrated variables, the long-run equilibrium relationship is estimated with the methodology proposed by Phillips and Hansen (1990) -fully modified estimation (FM)- and with a model of error correction mechanism (ECM) estimated non-lineally (NLLS). The first mitigates the second order biases that are produced in finite samples when estimating cointegration vectors with static regressions, and permits the use of standard asymptotic inference procedures. The second incorporates jointly the short-run dynamics and the process of adjustment to equilibrium, and offers a more efficient estimation of the long-run parameters. The existence of cointegration is tested for by applying the method of Engle and Granger (1987) on the residuals of the regression in the first case, and in the second the test of Banerjee, Dolado y Mestre (1998) on the adjustment parameter.

The possible instability of the parameters is examined using the tests SupF, MeanF y Lc developed by Hansen (1992). The three tests share the same null hypothesis -stability-, but present differences in the alternative. The first, SupF, tests for the existence of a regime shift; the second, MeanF, for the goodness of a model that contains a stable relationship; and lastly, the Lc is appropriate when the probability of parametric variation appears relatively constant throughout the sample, being at the same time a test of cointegration ( $H_{0}$ : cointegration; $H_{A}$ : no cointegration).

If these tests suggest non-stability, rejecting the null hypothesis of stability at the habitual levels of confidence, the analysis will be continued using the tests of Gregory and Hansen (1996) that examine the presence of cointegration with structural change. 
They are multivariate extensions of the tests of Perron (1989), Perron and Vogelsang (1992) and Zivot and Andrews (1992) which, under the alternative hypothesis, permit the change of the cointegration relationship at an unknown point of the sample period ( $H_{0}$ : no cointegration; $H_{A}$ : cointegration with structural change). Of the different modellings proposed by the authors, we have selected the model $\mathrm{C} / \mathrm{S}$, regime shift, considering it to be more adequate for the type of relationship analysed ${ }^{7}$. This family of tests, apart from being able to detect cointegration, offers an estimation of the date $(\tau)$ at which the structural change takes place. The expressions are as follows:

Starting from the initial model: $\mathrm{y}_{\mathrm{t}}=\alpha+\beta^{\prime} \mathrm{x}_{\mathrm{t}}+\varepsilon_{\mathrm{t}}$

a fictitious variable is defined $\varphi_{t \tau}=0$ if $\mathrm{t} \leq[\mathrm{n} \tau]$

$$
=1 \text { if } \mathrm{t}>[\mathrm{n} \tau]
$$

where $\tau \in(0,1)$ indicates the position of the unknown point of change.

The model C/S (regime shift) will have the following expression:

$$
\mathrm{y}_{\mathrm{t}}=\alpha_{1}+\alpha_{2} \varphi_{\mathrm{t} \tau}+\beta^{\prime}{ }_{1} \mathrm{x}_{\mathrm{t}}+\beta^{\prime}{ }_{2} \mathrm{x}_{\mathrm{t}} \varphi_{\mathrm{t} \tau}+\varepsilon_{\mathrm{t}}
$$

so that the break can be produced both in the independent term and in the parameter of the explanatory variables.

From the residuals of the previous regression estimated by ordinary least squares for all the possible break points covering all the sample except the initial and final $15 \%$, the minimum of the following tests of the family of the traditional ADF (augmented Dickey-Fuller) and Z (Phillips, Phillips-Perron) are selected:

$$
\begin{aligned}
& \operatorname{ADF}^{*}=\inf _{\tau \in \mathrm{T}} \operatorname{ADF}(\tau) \\
& \mathrm{Z}_{\alpha}{ }^{*}=\inf _{\tau \in \mathrm{T}} \mathrm{Z}_{\alpha}(\tau) \\
& \mathrm{Z}_{\mathrm{t}}{ }^{*}=\inf _{\tau \in \mathrm{T}} \mathrm{Z}_{\mathrm{t}}(\tau)
\end{aligned}
$$


Once the break point that minimises the test of the cointegration relationship has been obtained, the results of the estimation of the export and import functions are analysed, checking whether the change affects the whole vector of explanatory variables or only part of them. Finally, we explore the possibility that the series affected by the break may present a change in their integration order, using the tests proposed by Fernández and Peruga $(1999,2005)^{8}$. The analysis is carried out on the basis of the following regressions:

$$
\begin{aligned}
& \Delta Y_{t}=\mu+\alpha_{1}\left[1-D_{t t}\right] Y_{t-1}+\sum_{i=1}^{K} \delta_{i} \Delta Y_{t-i}+u_{t} \\
& \Delta Y_{t}=\mu+\alpha_{2} D_{\tau t} Y_{t-1}+\sum_{i=1}^{K} \delta_{i} \Delta Y_{t-i}+u_{t} \\
& \Delta Y_{t}=\mu+\gamma_{1} D_{\tau t} Y_{t-1}+\gamma_{2}\left[1-D_{\tau t}\right] Y_{t-1}+\sum_{i=1}^{K} \delta_{i} \Delta Y_{t-i}+u_{t} \\
& \mathrm{D}_{\tau t}=0 \quad \mathrm{t}<[\tau \mathrm{T}] \\
& \tau \in(0,1) \\
& \mathrm{T}>=[\tau \mathrm{T}]
\end{aligned}
$$

According to Fernández and Peruga $(1999,2005)$, it can be considered that the parameter $\delta$ is not constant throughout the sample period and, in consequence, the integration order of the stochastic process will change depending on the subsample considered. So for every possible break point the statistics $t \alpha_{1}, t \alpha_{2}, t \gamma_{1}$ and $t \gamma_{2}$ are calculated. The first is the $\mathrm{t}$ statistic associated with the null hypothesis $H_{0}: \alpha_{1}=0$ in the first regression, where the existence of a unit root in the first part of the sample is tested for. The next represents the $\mathrm{t}$ statistic for the null hypothesis $H_{0}: \alpha_{2}=0$ in the second regression, that is, the existence of a unit root in the second part of the sample. The last 
two represent the $\mathrm{t}$ statistics associated with the null hypotheses $H_{0}: \gamma_{1}=0$ and $H_{0}: \gamma_{2}=0$ in the third regression, or in other words, the existence of unit roots in the first or in the second part of the sample, respectively. Given that a sequential approach is being applied, the two statistics that we take are the supreme and the mean, as suggested by Hansen (1992), giving these values the names Sup $t \alpha_{1}$, Mean $t \alpha_{1}$, Sup $t \alpha_{2}$, Mean $t \alpha_{2}$, Sup $t \gamma_{1}$, Mean $t \gamma_{1}$, Sup $t \gamma_{2}$ and Mean $t \gamma_{2}$. Following the indications of Zivot and Andrews (1992), the observation in which the supreme is produced is taken as the estimator of the break point. These observations are called TSup $t \alpha_{1}$, TSup $t \alpha_{2}$, TSup $t \gamma_{1}$ and TSup $t \gamma_{2}$.

\section{Results of the estimation}

\subsection{The export function}

The estimated export function is, as in the majority of previous studies, a demand function, and includes, also as in previous studies, the two determinants habitual under a demand approach: income -a variable of scale or level- and prices -a variable of competitiveness ${ }^{9}$. As a variable of scale we have opted finally for the Gross Domestic Product of the OECD countries (gdpoecd), although at first we also specified the function with the imports of the developed block, an area considered relevant in the analysis Spanish exports. As for the competitiveness variable, we introduced the index of real effective exchange rates calculated both with production prices (ree) and with consumer prices, the latter, perhaps, less appropriate to measure the competitive level of a determined nation, and in both cases against the prices of the industrialised countries, accepted as the main competitors of Spanish exports.

The results of the long-run estimation using the Phillips-Hansen method are presented in Table 1. The Gross Domestic Product of the developed countries turns out to be highly significant in the long-run estimation of Spanish exports with a very high 
elasticity, around 3. Prices, on the other hand, show a lower significance and a much less elastic behaviour $(-0,6)$. A similar result is obtained estimating the long-run relationship with its short-run dynamics using non-lineal techniques -Table 2. In the long run, the coefficient of the variable of scale is also around 3 and the exchange rate reaches an elasticity of $(-0,8)$. In the short run, the variation of the GDP lagged one period is significant -which due to the dynamics of the short-run adjustment takes a negative sign $(-1,4)$, contrary to that presented by the contemporary first difference- and the change in prices now unlagged $(-0,5)$, with the expected sign and an elasticity inferior to that of the long run. At first, then, this would corroborate a more relevant role in export sales for the income variable than for the competitiveness variable. However, the results with respect to the existence of a cointegration relationship are ambiguous, because the ADF-EG test on the residuals of the FM estimation do not permit the rejection of the presence of a unit root, while the estimated parameter of the error correction mechanism is negative and significant, surpassing the critical values tabulated by Banerjee et. al (1998). The possibility that a structural break is biasing the results of the cointegration tests towards the acceptance of the null hypothesis should be, therefore, taken into account.

Moreover, examining the data for the export of goods between 1986 and 2000 Graph 1- points to the possibility of a structural break in the early nineties -around 1993-, when export sales seem to accentuate their upward trend. Furthermore, the evolution of the economic situation and the development of one of the two basic explanatory variables, the index of real effective exchange rates, strengthen the hypothesis of the existence of a possible break -see Graph 2. From 1993 onwards, not only does Europe join the expansive cycle initiated previously by the USA, but also the Spanish economy starts out on the path towards macroeconomic stability and Monetary 
Union. Having overcome the crisis of the European Monetary System that resulted in three devaluations of the peseta, the series of real exchange rates levels off and maintains a new profile -except for the devaluation of 1995- until the fixing of the conversion rates to the euro in May 1998, backed up both by the nominal exchange rate and the strong price convergence that occurred after $1996^{10}$. The results of applying the tests of parametric instability with the battery of tests of Hansen (1992) confirm the intuition of a structural break. In effect, both the SupF and the MeanF reject the existence of a stable relationship in the export function as does the Lc with the presence of cointegration (Table 3).

The application of the method proposed by Gregory and Hansen (1996) allows us to accept the cointegration hypothesis with a regime shift situated in the first quarter of 1993 (Table 4). The estimation of the coefficients presented in the same table show that the structural break is significant when it affects the independent term and the price elasticity, but not in the parameter that accompanies the income variable.

The results of the estimation of the error correction mechanism model after introducing the structural break in 1993 only in the price variable, given that the parameter $\beta_{2}$ is not significant in the regime shift model, are those expected a priori in the scenario described (Table 5). Around 1993, competitiveness via prices suffered an intense loss of weight becoming an almost irrelevant variable after this date -the real exchange rate parameter passes from being $(-1,5)$ to $(-0,1)$. A peseta tied first to stability because of the nominal convergence criteria, also to a fixed and irrevocable exchange rate with respect to the euro and, finally to its substitution by the single currency, would explain, together with a more and more controlled differential inflation, the scant role of the real exchange rate in the determination of Spanish exports to its European partners in the final years of the century ${ }^{11}$. On the short-run side, the lagged endogenous variable 
is almost significant with a coefficient around 0,2 , the speed of adjustment to the longrun equilibrium decreasing its exclusion from 0,9 to 0,8 but not the explanatory power of the model. The lagged change in income $(-1,9)$, the contemporary variation of prices $(-0,5)$ and the lagged $(0,4)$, as well as the dummy $93(\mathrm{I})$ introduced after the break point also reach significance.

With respect to the relevance of the other determinant -income- the results do not differ substantially from previous works, being highly significant and giving high coefficients, always superior to one. However, although the values of the coefficient around 3- are not very different, in none of the previous analyses has such an elastic behaviour of exports with respect to external income been found. These results could be explained by the peculiarities of the period under analysis. Being the years after the integration of Spain in the European Communities and, thus, of modernisation, integration and convergence, a slightly higher value does not seem strange, indicative of specialisation in fields of greater technological content and in products of higher quality ${ }^{12}$.

\subsection{The import function}

In the estimation of imports, again only the demand side is considered. The supply of foreign goods for import is perfectly elastic, and this eliminates the introduction of biases in the values of the parameters in spite of considering only the demand function. If the country is relatively small so that its demand of imported goods does not affect the determination of the prices on international markets, the supposition of nonsimultaneity between supply and demand is perfectly reasonable. The import of goods can be explained, in the same way as exports, by the two key variables in the determination of foreign trade flows: income and competitiveness, expressing the volume of Spanish imports in function of the real domestic income and the relative 
prices. To represent Spanish income, we have chosen the GDP, but disaggregated into its principal components -consumption (cons), investment (inv) and exports (export)-, although we tried modelling with the series of final and domestic demands ${ }^{13}$. Competitiveness, as in sales, was measured against the most developed countries especially in terms of production prices, although we also carried out estimations with consumer prices.

A first approximation to both determinants through the FM estimation, gives the expected role and sign to the scale and price variables as well as passing the cointegration tests (Table 6). On the income side, the maximum elasticity is obtained for consumption (it reaches unity) as opposed to a lower, although highly significant, level for exports $(0,7)$, and for investment $(0,1)$, the least relevant of the three ${ }^{14}$. As for the elasticity of prices, it reaches 0,8 , a coefficient that is not maintained in the specification of the ECM where the real exchange rate loses its significance in the long run(Table 7). The income side experiences minor changes: consumption continues to register the highest elasticity $(1,7)$, now even higher, while the parameters of investment and exports are both very close to 0,4 , the former increasing with respect to the FM estimation and the latter decreasing. In the short term, the contemporary variations of the two variables are again significant with similar coefficients once more $(0,3$ and 0,4 , respectively) and practically identical to those of the long term. Nevertheless the lagged investment and exports are not relevant while the variation of consumption is only relevant with a lag. As for prices, here they are significant: the difference in competitiveness presents the correct sign and a value of 0,6 .

Looking at the graph of the series of imports and of trade flow evolution, the atypical behaviour is centred in the second half of the period, from 1992-1994 onwards when, in spite of the devaluations of the peseta and its later tendency to stability, the 
purchase of goods continues its rising trend at a good rate, driven by the strength of economic activity and a rising domestic demand. Again, and as on the export side, there is evidence of a structural break. Particularly, the SupF and MeanF tests again strongly indicate a structural break, especially the former which suggests the existence of a regime shift (Table 8). However, the Lc test does not permit us to reject the null hypothesis of stability and cointegration.

For their part, the GH cointegration tests under the structural change also support the same hypothesis. The regimen shift model indicates the point of change in the year 1993, in the second quarter, and again the parameter of the explanatory variable real exchange rate is only altered significantly from that moment on (Table 9) ${ }^{15}$. After the second quarter prices again have little to say compared to income in Spanish trade (the coefficient changes from 1,1 to 0,1$)$. In the NLLS estimation, the change in behaviour of the competitiveness factor is only present in the short-term, long-run prices being non-significant (Table 10) ${ }^{16}$. While the elasticity of the real exchange rate before the break date is 0,8 , it falls from that moment on to under 0,2 . The behaviour of the other variables considered in the short run is practically unchanged, while in the long run the disaggregated income again is the most important with a coefficient around 1,7 for consumption, 0,3 for investment and 0,4 for exports.

As for the demand determinant, as on the export side, high income elasticities are obtained $^{17}$. Nevertheless, the consumption and the export coefficients $(1,6$ y 0,4$)$ are inferior to those presented in García and Gordo (1998) (2,7 and 0,5), the only work in this case with which a comparison can be established, and only higher for investment $(0,3$ as opposed to 0,2$)$. 


\section{The effects of nominal convergence}

The results obtained in the last section, compared to those of previous works, give, as the most important novelty, the existence of a structural break in the relative prices variable, and its loss of explanatory capacity both in the export and import functions. The extension of the period under analysis until the effective implantation of the euro, taking in the process of nominal convergence has, without doubt, favoured the obtaining of this conclusion.

Nevertheless, and with respect to the export trade flows, it is worth pointing out that, in spite of not having been detected or proved by any previous analyses, because they missed out the last years of the nineties -the crucial years of nominal convergence-, some of them do give interesting results for a first approximation to the question [Buisán and Gordo (1997), Mauleón and Sastre (1996) and Montañés and Sanso (2000)], or, at least, intuitions about the expected behaviour in the near future [García and Gordo (1998)].

For example, Buisán and Gordo (1997) note the limited capacity of the model until 1992 to predict the trade flows of 1993-1994 and the lower impact in the short run of the variations in competitiveness on the modelling of exports until 1995, something also observed in the sales estimations of Mauleón and Sastre (1996) until 1992 and 1994. Montañés and Sanso (2000) in their simulation exercises, anticipate a gradual reduction in the deficit of the sub-balance of manufactured goods, even though the detected structural break after European integration meant an increase in imports and a decrease in exports for given values of the explanatory variables; and they refer to the atypical behaviour of all the simulations between 1992 and 1996, especially of manufactured goods, which narrow, extraordinarily, the gap between imports and exports, the latter even surpassing the former, when this was not really so. Lastly, 
García and Gordo (1998) point out that in the second half of the nineties the relative weight of the competitiveness variables was much reduced, both in exports and in imports, as a consequence of exchange rate stability and of the strong price controls that were imposed in the country during this period. All these indices point to the strength of Spanish sales against the real exchange rate under the requirement of macroeconomic stability, and with a single currency shared with its principal trade partners -exports to the European Union make up about three quarters of the total in 2000.

The results derived from the analysis of the import flow show similar aspects to that of exports. Spanish foreign purchases lose sensitivity to prices after the devaluations of the early nineties, a change contained in the FM estimation, and reflected only in the short run in the ECM, where long-run prices are not significant. Furthermore, as with exports, other studies -that do not undertake the analysis of trade in the last years of the decade- found anomalous behaviours in the import functions with respect to the determinant exchange rate; to be expected, nevertheless, when in the second half of the nineties, in spite of the exchange rate showing a more stable situation, although less favourable for foreign purchases with the recuperation in the first half of the competitiveness lost at the end of the eighties, imports continue to grow at a more than noteworthy rhythm. So it does not appear that it is prices that explain the increase. Signs of this appear in Buisán and Gordo (1997), Montañés and Sanso $(2000,2002)$ and García and Gordo (1998). The first authors reveal, in the short term, the decrease -in absolute value- of the parameter of the change in prices on adding the last three years 1992-1995 to the estimation, while in the long run they observe a similar behaviour following the Johansen methodology. Montañés and Sanso $(2000,2002)$ also indicate, in the imports of manufactured products, a significant change in the short-run elasticity of the nominal exchange against Community countries, from 1986 on, whereas in the 
long run the variation of the real exchange rate is small. Finally, García and Gordo (1998) show, for imports and when they consider the disaggregated final demand, that the equations proposed until 1996 do not pass the tests of stability of the parameters during the period 1993-1996, as well as suspecting some loss of explanatory capacity of the variable real exchange rate in the period of exchange stability and price convergence.

Given these results we have opted to study in greater depth the nature of the changes that affect the real effective exchange rate, analysing not only whether it has modified its behaviour in the trade functions, but also the stochastic properties of the series. The results of applying the test for a change in the integration order of Fernández and Peruga $(1999,2005)$ show that, in effect, the series has changed from presenting a unit root in the first part of the sample to being stationary in the second (Table 11). Of all the series analysed, only the ree surpasses the critical values of the tests at the $1 \%$ level, the change in the integration order being between the third quarter of 1992 and the first of 1993. These results illustrate that the devaluations that brought about the adjustment of the nominal exchange rate, together with its later stability and the convergence of prices, have modified the character of the series, explaining its peculiar behaviour in the export and import functions.

In consequence, and although the series is $\mathrm{I}(1)$ for the complete sample, it is interesting to ask to what extent it is relevant to estimate cointegration relationships, of long-run equilibrium, when one of the variables included lacks a unit root in the second part of the sample, and so of long-run effect. In fact, the variation in the order of integration detected for the index of real effective exchange rate series, which changes from being I(1) until 1992 to I(0) from then on, would imply the incorporation of this variable in the short run after the break, and at levels and differentiated in the first 
period. In accordance with the above, we have re-estimated the ECM models for exports and imports with NLLS incorporating the variable exchange rate only in the long run in the first sample period, and in the short run at levels and differences discriminating by periods (Tables 12 and 13).

With respect to exports the results are not substantially different to those obtained when considering the series as I(1) during the whole period, but they do offer some interesting nuances. Although both income elasticity and the adjustment of the equilibrium relationship hardly change, the exchange rate is significant and has the expected sign during the first period with an elasticity close to one, being significant in the short run in the second period. So the negative and structural influence that the real appreciation of the peseta had during the years after joining the EEC is maintained.

The import function is more interesting. In this case, and if we consider the estimation with the disaggregated income, the exchange rate, although it presents the expected sign, is not significant in the long run during the first period. Neither is it significant in the short run during the second period though it is in the first. Therefore, imports are much less sensitive to the price variable, reacting only to its variations during the first years after 1986 and before its stabilisation.

To sum up, the results of modelling the export and import functions after incorporating the change in the integration order of the real effective exchange rate, corroborate the loss of explanatory power of the price variable for the export and import flows. Likewise, they maintain the higher sensitivity of exports to the price variable, significant in the long run in the first period and in the short run in the second, compared with imports for which only the price variations in the first period are relevant. With respect to income, the elasticity of the import function is invariably higher than that of the export function. 
From the previous results two conclusions can be drawn. In the first place, that the relevance of the real exchange rate could have ended before the new conditions defined by the introduction of the single currency. Without exchange rates, foreign exchange restrictions or monetary control, the real economy becomes more important within the Eurozone. However, to flatly affirm that competitiveness via prices has ceased to be relevant, is perhaps a premature and risky conclusion. Firstly, because the index of the real effective exchange rate -measured in production prices- is only a partial measure of competitiveness. It would be desirable to include other measures such as general price indexes or, especially, labour costs. And secondly, because, as our period of analysis finishes with the introduction of the euro, the first indications of what happened after the single currency have been eliminated. After successfully finishing the nominal convergence in 1998, there began a period of increasingly higher differential inflation and of unit labour costs increased by low productivity, which has possibly broken the trend towards macroeconomic stability. We should ask ourselves, therefore, if the change in the order of integration of the real exchange rate is of a permanent character or if it has been only a passing illusion, the fruit of the accelerated efforts to fulfil the criteria of Maastricht ${ }^{18}$.

The recent behaviour of the trade balance -and this would be the second conclusion - already points in this direction -Graph 1 . Its evolution shows that, after a period of stability, the trade deficit has grown again, driven by an expanding domestic demand, and by rises in prices and costs. The estimated parameters of the functions are coherent with such an evolution. If exports have suffered, without doubt, from international uncertainty, given their high income elasticity, they might have been further affected -given their greater reaction to the real exchange rate- by a new worsening of the macroeconomic conditions. At the same time imports maintain an 
intense rhythm of growth even when the economic situation begins to weaken, sustained by consumption. These changes in the trade flows have broken the reiterated trend of narrowing the trade gap that some works noted.

\section{Conclusions}

Looking at both the exports and import functions allows us to draw some conclusions, not only to understand the Spanish foreign sector in the final years of the last century better, but also as a lesson for the future, because what happened in those years could be a good indication of what is going to happen in the $21^{\text {st }}$ century, an indicator of the capacity of the Spanish economy to compete in a new scenario without exchange rates. These conclusions could be extended, if later studies corroborate them, to the other member states of the Economic and Monetary Union (EMU), especially those countries on the periphery of Europe, where the efforts to achieve monetary integration have necessarily been -as in Spain- greater.

After the two years of devaluations, years detected as a break point in the estimations of the trade functions, the old role of the real exchange rate, one of the basic macroeconomic determinants of foreign trade flows until then, loses its strength in trade specification. Due to the process of nominal convergence initiated in those years, the series of the index of real effective exchange rates changes from being of first order integration until 1992 to being of zero order integration afterwards, thus indicating the structural break produced. As a result, from that moment on it loses most of its capacity, especially in the long term, to determine trade flows, income taking its place.

It is, therefore, difficult to explain the trade of the period as a unity and we end up drawing two stages: the first between 1986 and 1992 and the second from 1993 to 2000. In the first, income and competitiveness continue their importance along the lines of previous periods, the strong sensitivity in the long run of exports to a exchange rate 
characterised by its appreciation being highlighted; in the second, the variable of scale takes on the leading role in the relationship and takes away importance from prices, transferring the challenge to be competitive to other fronts. This result is nothing more than a consequence of the place that other non-monetary determinants of competitiveness occupy in the explanation of international trade. They are factors such as economies of scale or product differentiation, linked in the last instance to technological progress and recognised by the neo-classical theoretical paradigm as decisive determinants of the volume and the composition of present $\operatorname{trade}^{19}$.

To sum up, after 1993 we can already notice the effects of the structural break that the euro is provoking on the Spanish foreign sector of the new century, which, from that moment on, operates within a double exchange scenario: fixed with respect to a new trade area that accounts for two thirds of its trade, and floating against the rest. The nominal convergence prior to monetary integration, has modified the behaviour of the Spanish export and import functions, advancing the new elements that are going to rule trade in the future. It would be, nevertheless, too daring to totally discard competition through prices as a trade determinant. The measurement of the real exchange rate on the basis of variables that do not include other cost factors, and the accelerated process of adjustment experienced in the period of fulfilling the requirements of the single currency, make it necessary to be careful. 
Figure 1: Evolution of exports, imports and trade balance with respect to the GDP

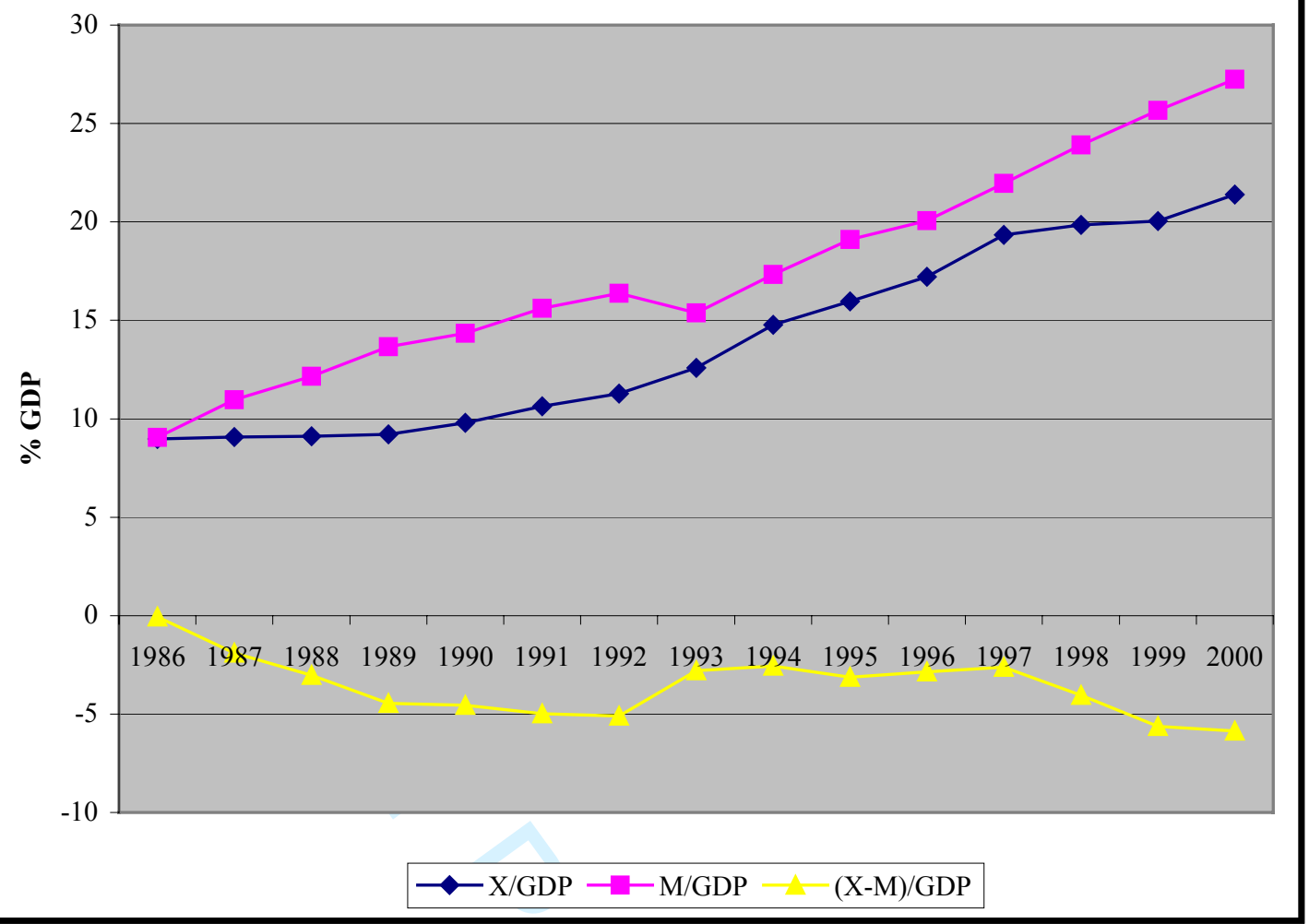

Figure 2: Evolution of determinants of foreign trade

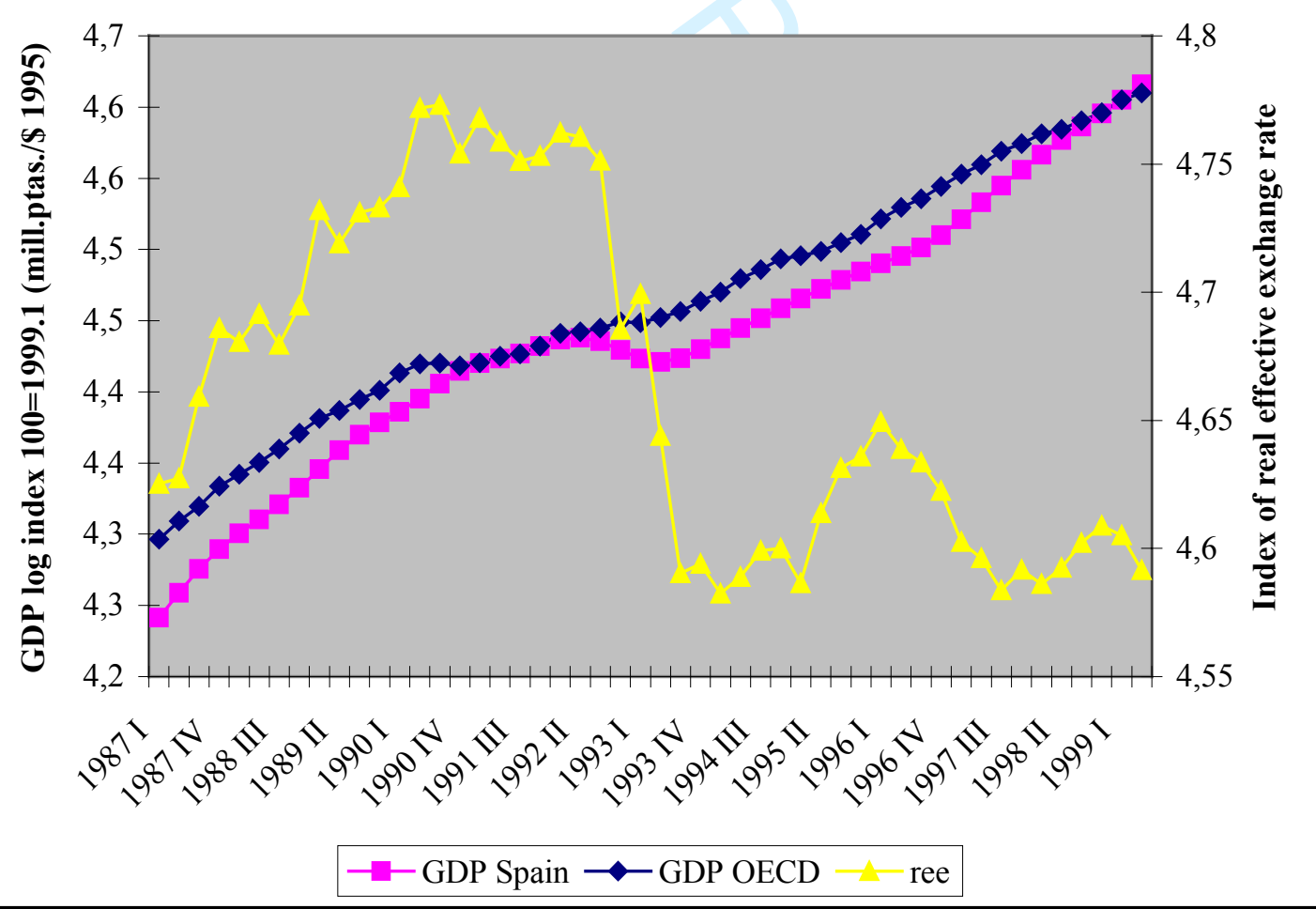


Table 1. Estimation of the exports of goods, 1987-1999. FM-PH

\begin{tabular}{ll}
\hline Constant & -6.64 \\
& $(-6.79)$ \\
gdpoecd & 3.05 \\
& $(35.81)$ \\
ree & -0.61 \\
& $(-3.38)$ \\
\hline ADF-EG & -2.83
\end{tabular}

Notes: We use Parzen's window with a truncation parameter=4. The number of lags in the EG cointegration test is carried out according to the $\mathrm{Ng}$ and Perron (1995) method starting with a maximum lag of 8 . t-ratios in brackets; *significant at the $5 \%$ level; ** significant al the $1 \%$ level.

Table 2. Estimation of the exports of goods, 1987-1999. NLLS

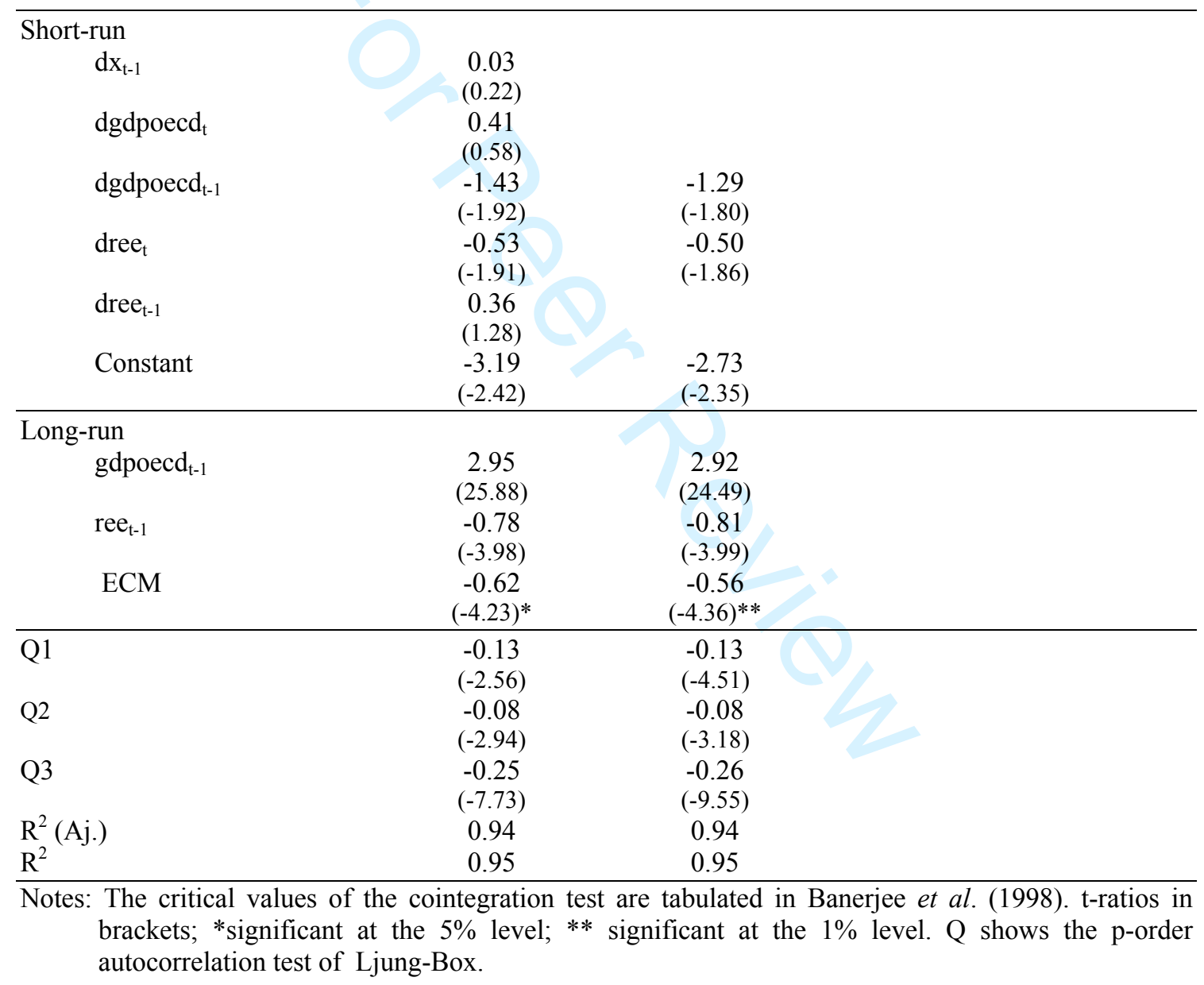


Table 3. Stability parameter test for the goods exports function

\begin{tabular}{|l|c|c|}
\hline & Test & p-valor \\
\hline SupF & 19.27 & 0.01 \\
\hline MeanF & 6.51 & 0.04 \\
\hline Lc & 0.83 & 0.02 \\
\hline
\end{tabular}

Notes: The critical values are tabulated in Hansen (1992). The fully-modified estimation uses a quadratic kernel following his proposal. We also follow the selection method of bandwidth parameter included in the GAUSS program provided by Hansen.

\section{Table 4. Gregory-Hansen test of the model $\mathrm{C} / \mathrm{S}$ (regime change) for the goods exports function}

Estimation of the coefficients:

$$
\begin{aligned}
& \mathrm{y}_{\mathrm{t}}=\alpha_{1}+\alpha_{2} \varphi_{\mathrm{t \tau}}+\beta_{1} \text { gdpoecd }_{\mathrm{t}}+\beta_{2} \operatorname{gdpoecd}_{\mathrm{t}} \varphi_{\mathrm{t} \tau}+\gamma_{1} \text { ree }+\gamma_{2} \text { ree } \varphi_{\mathrm{t} \tau}+\varepsilon_{\mathrm{t}} \\
& \alpha_{1}=-4.38 \quad-4.33 \\
& (-2.25) \quad(-2.30) \\
& \alpha_{2}=-8.24 \quad-8.15 \\
& (-1.89) \quad(-1.91) \\
& \beta_{1}=3.44 \quad 3.51 \\
& \text { (5.42) (13.05) } \\
& \beta_{2}=0.08 \\
& \gamma_{1}=-1.44 \\
& -1.51 \\
& \gamma_{2}=1.66
\end{aligned}
$$

\section{Gregory-Hansen test:}

$\begin{array}{ccc}\mathrm{ADF} & -4.30 & \tau=93(\mathrm{I}) \\ & (0.48) & \\ \mathrm{Z}_{\mathrm{t}} & -11.29 * * & \tau=93(\mathrm{I}) \\ & (0.30) & \\ \mathrm{Z}_{\alpha} & -69.08^{* *} & \tau=93(\mathrm{I}) \\ & (0.30) & \end{array}$

Notes: The critical values are tabulated in Gregory and Hansen (1996). T-ratios in brackets in the estimation of coefficients. In the GH test the error standard is in brackets. *significant at the $5 \%$ level; ** significant at the $1 \%$ level. 
Table 5. Estimation of the exports of goods with a break in the exchange rate, 1987-1999. NLLS

\begin{tabular}{|c|c|c|c|}
\hline Short-run & & & \\
\hline $\mathrm{dx}_{\mathrm{t}-1}$ & $\begin{array}{c}0.25 \\
(1.59)\end{array}$ & $\begin{array}{c}0.25 \\
(1.63)\end{array}$ & \\
\hline dgdpoecd $_{t}$ & $\begin{array}{c}0.40 \\
(0.58)\end{array}$ & & \\
\hline $\operatorname{dgdpoecd}_{\mathrm{t}-1}$ & -1.91 & -1.93 & -1.50 \\
\hline & $(-2.67)$ & $(-2.74)$ & $(-2.18)$ \\
\hline dree $_{t}$ & -0.55 & -0.56 & -0.51 \\
\hline & $(-2.03)$ & $(-2.05)$ & $(-1.84)$ \\
\hline dree $_{t-1}$ & 0.41 & 0.44 & \\
\hline & $(1.50)$ & $(1.67)$ & \\
\hline D93(I) & -6.28 & -6.41 & -4.83 \\
\hline & $(-2.75)$ & $(-2.85)$ & $(-2.35)$ \\
\hline Constant & -3.55 & -3.40 & -2.49 \\
\hline & $(-2.89)$ & $(-2.86)$ & $(-2.22)$ \\
\hline Long-run & & & \\
\hline $\operatorname{gdpoecd}_{\mathrm{t}-1}$ & 3.36 & 3.34 & 3.31 \\
\hline & (26.71) & (27.07) & $(22.16)$ \\
\hline ree $_{t-1}$ & -1.48 & -1.49 & -1.52 \\
\hline & $(-6.16)$ & $(-6.27)$ & $(-5.08)$ \\
\hline D93(I)*ree ${ }_{t-1}$ & 1.38 & 1.42 & 1.33 \\
\hline & $(3.52)$ & $(3.70)$ & $(2.76)$ \\
\hline ECM & -0.96 & -0.95 & -0.76 \\
\hline & $(-5.33)^{* *}$ & $(-5.35)^{* *}$ & $(-5.20)^{* *}$ \\
\hline Q1 & -0.14 & -0.14 & -0.09 \\
\hline & $(-3.00)$ & $(-3.09)$ & $(-2.84)$ \\
\hline Q2 & -0.05 & -0.05 & -0.04 \\
\hline & $(-1.83)$ & $(-1.81)$ & $(-1.66)$ \\
\hline Q3 & -0.24 & -0.24 & -0.22 \\
\hline & $(-7.66)$ & $(-7.80)$ & $(-7.69)$ \\
\hline $\mathrm{R}^{2}(\mathrm{Aj})$. & 0.95 & 0.95 & 0.95 \\
\hline $\mathrm{R}^{2}$ & 0.96 & 0.96 & 0.96 \\
\hline
\end{tabular}

Notes: See Table 2.

Table 6. Estimation of the goods imports function with the demand components disaggregated, 1987-1999. FM-PH

\begin{tabular}{lcc}
\hline Constant & -7.47 & -7.53 \\
gdpsp & $(-10.99)$ & $(-8.56)$ \\
& & 1.02 \\
cons & & $(5.67)$ \\
& 0.97 & \\
inv & $(7.46)$ & \\
& 0.12 & 0.05 \\
export & $(3.08)$ & $(1.00)$ \\
& 0.70 & 0.69 \\
ree & $(16.25)$ & $(13.80)$ \\
& 0.83 & 0.86 \\
ADF-EG & $(5.61)$ & $(5.06)$ \\
\hline
\end{tabular}

Notes: See Table 1. 
Table 7. Estimation of the goods imports function with the demand components disaggregated, 1987-1999, 1987-1999. NLLS

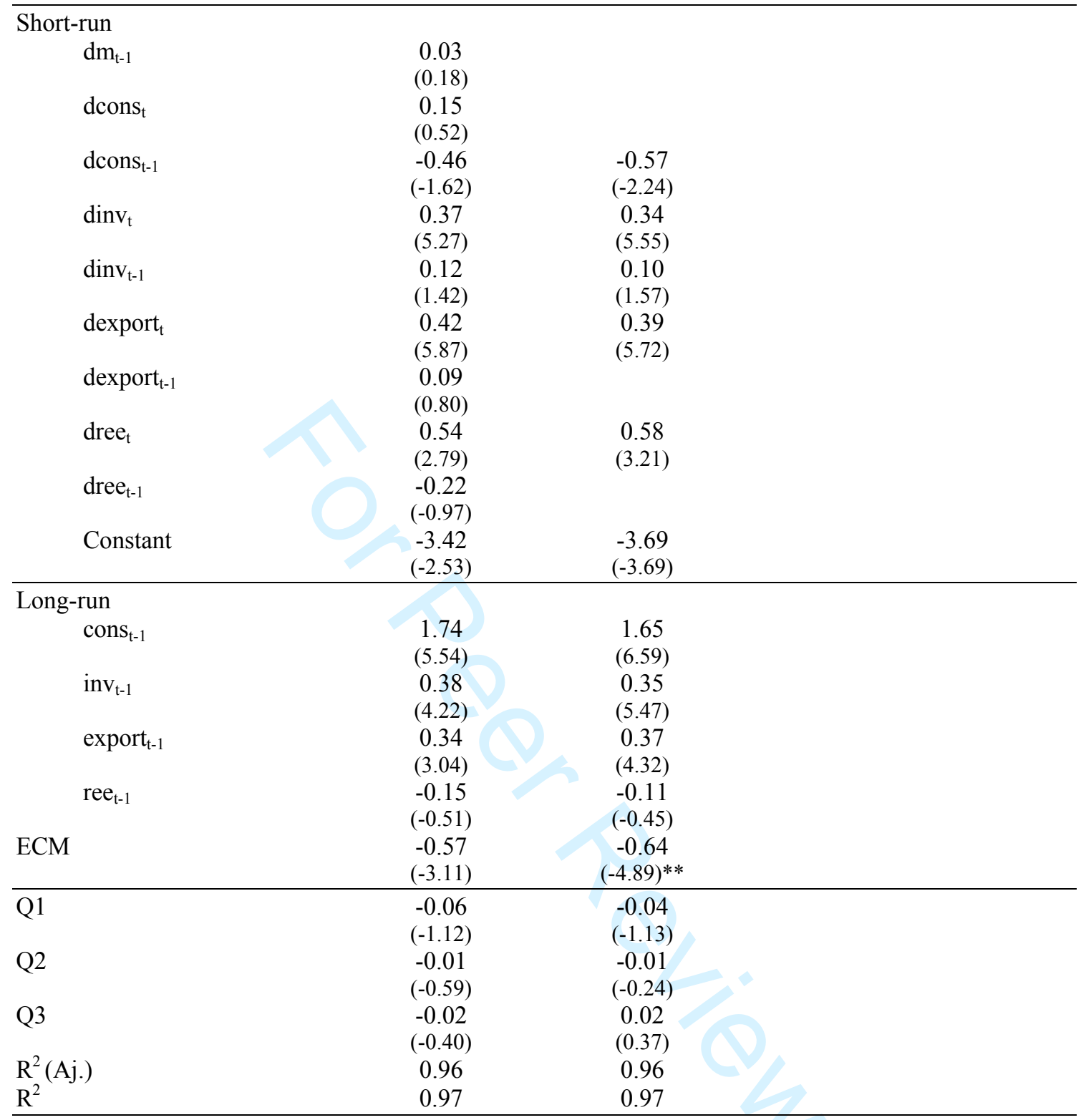

Notes: See Table 2.

Table 8. Stability parameter test for the imports function with the demand components disaggregated

\begin{tabular}{|l|c|c|}
\hline & Test & P-valor \\
\hline SupF & 103.39 & 0.01 \\
\hline MeanF & 21.91 & 0.01 \\
\hline Lc & 0.43 & 0.20 \\
\hline
\end{tabular}

Notes: See Table 3. 
Table 9. Gregory-Hansen test of the $\mathrm{C} / \mathrm{S}$ model for the goods imports function with the demand components disaggregated

$$
\begin{aligned}
& \text { Estimation of the coefficients: } \\
& \mathrm{y}_{\mathrm{t}}=\alpha_{1}+\alpha_{2} \varphi_{\mathrm{t \tau}}+\beta_{1} \text { cons }_{\mathrm{t}}+\beta_{2} \operatorname{cons}_{\mathrm{t}} \varphi_{\mathrm{t \tau}}+\delta_{1} \operatorname{inv}_{\mathrm{t}}+\delta_{2} \operatorname{inv}_{\mathrm{t}} \varphi_{\mathrm{tr}}+\theta_{1} \text { export }_{\mathrm{t}}+\theta_{2} \operatorname{export}_{\mathrm{t}} \varphi_{\mathrm{tr}}+\gamma_{1} \text { ree }+\gamma_{2} \text { ree }_{\mathrm{tr}_{\mathrm{t \tau}}}+\varepsilon_{\mathrm{t}} \\
& \alpha_{1}=-7.92 \quad-7.93 \\
& (-9.27) \quad(-10.86) \\
& \alpha_{2}=3.30 \\
& \text { (1.68) } \quad(2.60) \\
& \beta_{1}=0.70 \quad 0.71 \\
& \text { (4.84) (6.19) } \\
& \beta_{2}=0.14 \\
& \text { (0.52) } \\
& \delta_{1}=0.16 \quad 0.14 \\
& (2.89) \quad(3.92) \\
& \delta_{2}=-0.01 \\
& (-0.94) \\
& \theta_{1}=0.68 \quad 0.69 \\
& \text { (10.16) (17.30) } \\
& \theta_{2}=0.05 \\
& \gamma_{1}=1.15 \quad(0.54) \\
& \text { (4.44) (5.93) } \\
& \gamma_{2}=-0.80 \quad-0.98 \\
& (-2.08) \quad(-2.58)
\end{aligned}
$$

Gregory-Hansen test:

$\begin{array}{ccc}\mathrm{ADF} & -4.56 & \tau=93(\mathrm{II}) \\ & (0.50) & \\ \mathrm{Z}_{\mathrm{t}} & -6.56^{*} & \tau=93(\mathrm{II}) \\ & (0.20) & \\ \mathrm{Z}_{\alpha} & -47.90 & \tau=93(\mathrm{II}) \\ & (0.20) & \end{array}$

Notes: See Table 4. 
Table 10. Estimation of the goods imports function with the demand components disaggregated, 1987-1999. NLLS

\begin{tabular}{|c|c|c|}
\hline \multirow{2}{*}{\multicolumn{3}{|c|}{ Short-run }} \\
\hline & & \\
\hline dcons $_{t-1}$ & $\begin{array}{c}-0.52 \\
(-2.12)\end{array}$ & $\begin{array}{c}-0.51 \\
(-2.16)\end{array}$ \\
\hline \multirow[t]{2}{*}{$\operatorname{dinv}_{t}$} & 0.32 & 0.32 \\
\hline & (5.28) & (5.38) \\
\hline \multirow[t]{2}{*}{$\operatorname{dinv}_{t-1}$} & 0.11 & 0.11 \\
\hline & (1.71) & (1.78) \\
\hline \multirow[t]{2}{*}{ dexport $_{t}$} & 0.38 & 0.39 \\
\hline & $(5.72)$ & $(6.16)$ \\
\hline dree $_{t}$ & 0.84 & $\begin{array}{c}0.86 \\
(4.28)\end{array}$ \\
\hline \multirow{2}{*}{ dree $_{t}^{*}$ D93(II) } & -0.66 & -0.67 \\
\hline & $(-1.91)$ & $(-1.98)$ \\
\hline \multirow[t]{2}{*}{ Constant } & -3.62 & -3.75 \\
\hline & $(-3.76)$ & $(-4.68)$ \\
\hline \multicolumn{3}{|l|}{ Long-run } \\
\hline $\operatorname{cons}_{t-1}$ & 1.68 & 1.64 \\
\hline \multirow{2}{*}{$\operatorname{inv}_{t-1}$} & 0.33 & 0.31 \\
\hline & & (7.39) \\
\hline \multirow{2}{*}{$\operatorname{export}_{t-1}$} & 0.38 & 0.39 \\
\hline & $(4.30)$ & $(9.37)$ \\
\hline \multirow{2}{*}{ ree $_{t-1}$} & -0.06 & \\
\hline & $(-0.25)$ & \\
\hline \multirow{2}{*}{ ECM } & -0.60 & -0.61 \\
\hline & $(-4.71)^{*}$ & $(-5.10)^{* *}$ \\
\hline \multirow[t]{2}{*}{ Q1 } & -0.06 & -0.06 \\
\hline & $(-1.51)$ & $(-1.61)$ \\
\hline \multirow[t]{2}{*}{ Q2 } & -0.01 & -0.01 \\
\hline & $(-0.42)$ & $(-0.43)$ \\
\hline \multirow[t]{2}{*}{ Q3 } & -0.003 & -0.01 \\
\hline & $(-0.08)$ & $(-0.11)$ \\
\hline $\mathrm{R}^{2}(\mathrm{Aj})$. & 0.96 & 0.96 \\
\hline $\mathrm{R}^{2}$ & 0.97 & 0.97 \\
\hline
\end{tabular}

Notes: See Table 2. 
Table 11. Tests of changes in the integration order

\begin{tabular}{|c|c|c|c|c|c|c|c|c|}
\hline & $\mathrm{x}$ & gdpoecd & $\mathrm{m}$ & gdpsp & ree & cons & inv & export \\
\hline $\operatorname{Sup} t \alpha_{1}$ & -1.76 & -2.00 & -2.11 & -2.93 & -2.30 & -2.34 & 2.27 & -1.95 \\
\hline Mean $t \alpha_{1}$ & -0.54 & -0.81 & -1.22 & -2.11 & -1.13 & -1.73 & -1.57 & -0.02 \\
\hline $\operatorname{TSup} t \alpha_{1}$ & 97.1 & 93.2 & 93.2 & 92.3 & 93.2 & 89.4 & 89.1 & 98.3 \\
\hline $\operatorname{Sup} t \alpha_{2}$ & -1.49 & -2.20 & -1.15 & -1.31 & $-4.32 * *$ & -1.50 & -1.44 & -2.18 \\
\hline Mean $t \alpha_{2}$ & -0.76 & -0.46 & -0.38 & -0.15 & -1.25 & -0.60 & -0.65 & -0.90 \\
\hline $\operatorname{TSup} t \alpha_{2}$ & 93.4 & 93.1 & 97.4 & 87.3 & 92.3 & 87.3 & 87.4 & 94.3 \\
\hline $\operatorname{Sup} t \gamma_{1}$ & -1.78 & -2.09 & -2.13 & -2.93 & -2.56 & -2.36 & -2.44 & -2.02 \\
\hline Mean $t \gamma_{1}$ & -0.67 & -0.83 & -1.28 & -2.22 & -1.21 & -1.74 & -1.75 & -0.17 \\
\hline $\operatorname{TSup} t \gamma_{1}$ & 90.1 & 93.1 & 93.4 & 94.3 & 93.1 & 97.2 & 97.4 & 90.4 \\
\hline $\operatorname{Sup} t \gamma_{2}$ & -1.58 & -2.28 & -1.22 & -1.03 & $-4.45 * *$ & -1.27 & -1.52 & -2.20 \\
\hline Mean $t \gamma_{2}$ & -0.87 & -0.44 & -0.37 & -0.20 & -1.37 & -0.56 & -0.99 & -0.99 \\
\hline $\operatorname{TSup} t \gamma_{2}$ & 93.4 & 93.1 & 97.4 & 97.4 & 92.3 & 89.2 & 97.1 & 94.3 \\
\hline
\end{tabular}

Notes: The critical values are tabulated in Fernández and Peruga (1999) *significant at the 5\% level; ** significant at the $1 \%$ level.

Table 12. Estimation of the goods exports function with change in the integration order of exchange rate, 1987-1999. NLLS

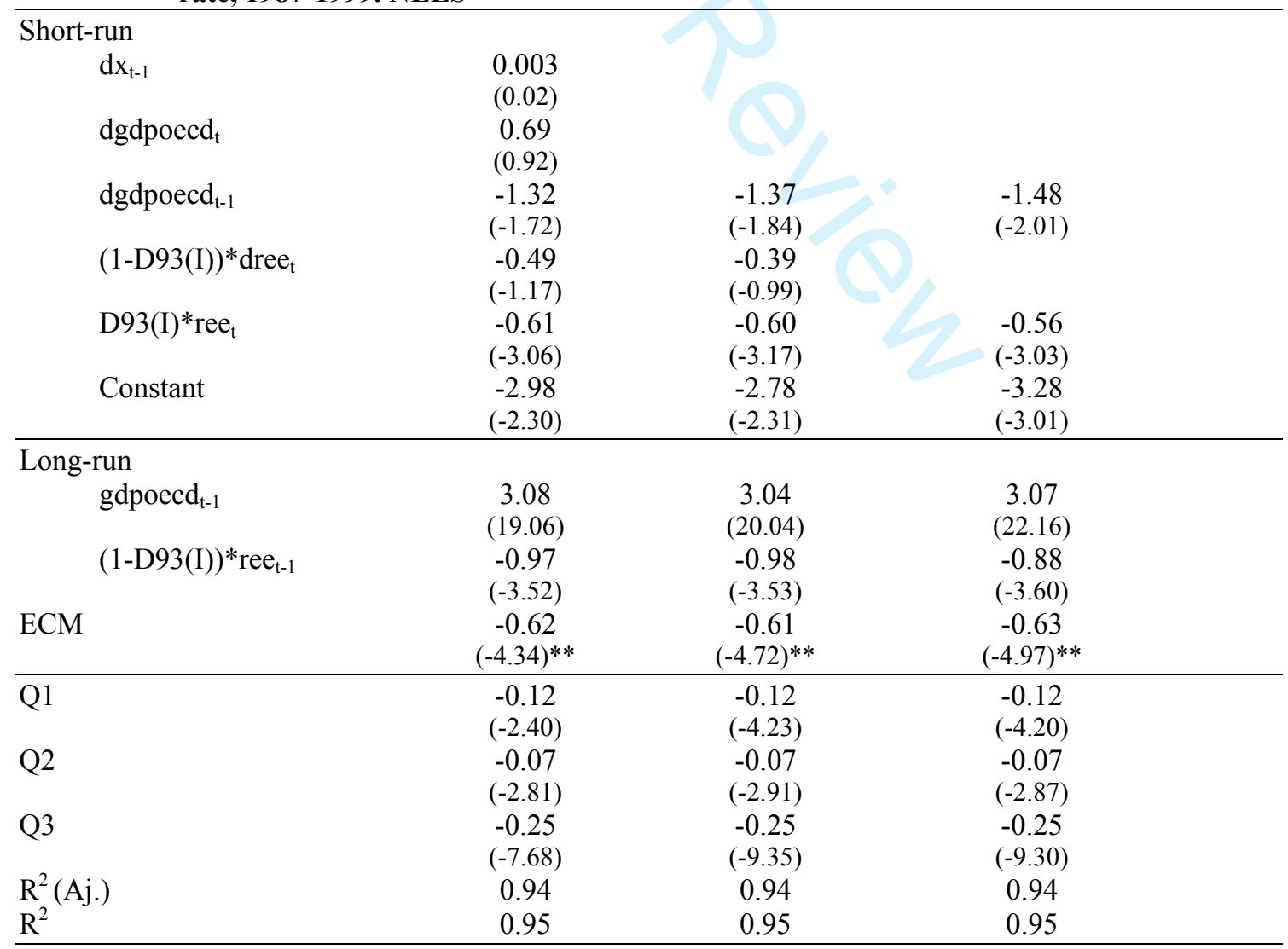

Notes: See Table 2. 
Table 13. Estimation of the goods imports function with change in the integration order of exchange rate, 1987-1999. NLLS

\begin{tabular}{|c|c|c|c|}
\hline \\
\hline $\mathrm{dm}_{\mathrm{t}-1}$ & $\begin{array}{l}0.002 \\
(0.01)\end{array}$ & & \\
\hline dcons $_{t}$ & $\begin{array}{c}0.02 \\
(0.06)\end{array}$ & & \\
\hline dcons $_{t-1}$ & $\begin{array}{l}-0.33 \\
(-1.13)\end{array}$ & & \\
\hline $\operatorname{dinv}_{t}$ & $\begin{array}{c}0.33 \\
(4.70)\end{array}$ & $\begin{array}{c}0.29 \\
(4.29)\end{array}$ & $\begin{array}{c}0.29 \\
(4.41)\end{array}$ \\
\hline $\operatorname{dinv}_{t-1}$ & $\begin{array}{c}0.14 \\
(1.46)\end{array}$ & & \\
\hline dexport $_{t}$ & $\begin{array}{c}0.43 \\
(5.98)\end{array}$ & $\begin{array}{c}0.45 \\
(6.12)\end{array}$ & $\begin{array}{c}0.44 \\
(6.26)\end{array}$ \\
\hline dexport $_{t-1}$ & & & $\begin{array}{c}0.08 \\
(0.67)\end{array}$ \\
\hline$(1-\mathrm{D} 93(\mathrm{II}))^{*} \mathrm{dree}_{\mathrm{t}}$ & $\begin{array}{l}0.73 \\
(2.54)\end{array}$ & $\begin{array}{c}0.77 \\
(2.86)\end{array}$ & $\begin{array}{l}0.76 \\
(2.94)\end{array}$ \\
\hline D93(II)* ree $_{t}$ & $\begin{array}{l}-0.08 \\
(-0.41)\end{array}$ & $\begin{array}{c}0.04 \\
(0.24)\end{array}$ & \\
\hline Constant & $\begin{array}{l}-3.05 \\
(-1.95)\end{array}$ & $\begin{array}{l}-2.67 \\
(-2.45)\end{array}$ & $\begin{array}{l}-2.48 \\
(-3.51)\end{array}$ \\
\hline \multicolumn{4}{|l|}{ Long-run } \\
\hline cons $_{t-1}$ & $\begin{array}{c}1.69 \\
(4.59)\end{array}$ & $\begin{array}{c}1.28 \\
(4.44)\end{array}$ & $\begin{array}{c}1.33 \\
(5.90)\end{array}$ \\
\hline $\operatorname{inv}_{t-1}$ & $\begin{array}{c}0.31 \\
(3.13)\end{array}$ & $\begin{array}{l}0.33 \\
(3.87)\end{array}$ & $\begin{array}{c}0.34 \\
(4.11)\end{array}$ \\
\hline export $_{t-1}$ & $\begin{array}{c}0.42 \\
(3.82)\end{array}$ & $\begin{array}{c}0.50 \\
(5.06)\end{array}$ & $\begin{array}{c}0.49 \\
(5.71)\end{array}$ \\
\hline$(1-\mathrm{D} 93(\mathrm{II}))^{*} \mathrm{ree}_{\mathrm{t}-1}$ & $\begin{array}{c}0.14 \\
(0.36)\end{array}$ & $\begin{array}{c}0.09 \\
(0.26)\end{array}$ & $\begin{array}{l}0.004 \\
(0.43)\end{array}$ \\
\hline ECM & $\begin{array}{l}-0.53 \\
(-2.60) \\
\end{array}$ & $\begin{array}{l}-0.48 \\
(-3.56) \\
\end{array}$ & $\begin{array}{l}-0.47 \\
(-4.20) \\
\end{array}$ \\
\hline Q1 & $\begin{array}{l}-0.09 \\
(-1.49)\end{array}$ & $\begin{array}{l}-0.02 \\
(-0.56)\end{array}$ & $\begin{array}{c}-0.02 \\
(-0.54)\end{array}$ \\
\hline Q2 & $\begin{array}{l}-0.02 \\
(-0.65)\end{array}$ & $\begin{array}{c}0.02 \\
(1.17)\end{array}$ & $\begin{array}{c}0.02 \\
(1.24)\end{array}$ \\
\hline Q3 & $\begin{array}{l}-0.01 \\
(-0.22)\end{array}$ & $\begin{array}{c}0.01 \\
(0.27)\end{array}$ & $\begin{array}{c}0.01 \\
(0.30)\end{array}$ \\
\hline $\mathrm{R}^{2}(\mathrm{Aj})$. & 0.95 & 0.95 & 0.95 \\
\hline $\mathrm{R}^{2}$ & 0.97 & 0.96 & 0.96 \\
\hline
\end{tabular}

Notes: See Table 2. 


\section{STATISTICAL APPENDIX}

Period: $1986-2000$

Periodicity: Quarterly (The number of observations of the sample is 50, from 1987 (I) to 1999 (II). 1986 is excluded from the analysis to avoid the problems of accounting changes produced in Spanish trade flows as a consequence of European integration.

Variables and statistical sources:

- Endogenous variables:

Exports and imports of goods (Dirección General de Previsión y Coyuntura)- $\mathrm{x}$ and $\mathrm{m}$

- Exogenous variables:

Gross Domestical Product OECD (OECD Main Economic Indicators and Quarterly National Accounts)- gdpoecd

Spanish Gross Domestical Product at market prices (Contabilidad Nacional Trimestral)- gdpsp

Spanish consumption expenditure (CNT)- cons

Spanish gross fixed capital formation in capital goods: machinery and equipment (CNT)- inv

Spanish goods exports (CNT)- export

IREER against the developed countries' production prices (Dirección General de Previsión y Coyuntura)- ree 


\section{NOTES} ${ }^{1}$ See Bacchetta and van Wincoop (2000), Baum et al. (2004), Lane and Milesi-Ferretti (2002), and Grier
and Smallwood (2003).

${ }^{2}$ Nachane and Ranade (1998) contrast different hypotheses about the effect of the real exchange rate on trade and find a very significant effect. Also Bahmani-Oskooe (2001) and In and Menon (1996) investigate how the exchange rate affects the trade balance and the terms of trade, respectively. Nevertheless, most of empirical studies analyse the impact of the exchange rate on exports [see, among others, Doyle (2001), Morgenroth (2000), Aristotelous (2002), Nabli and Véganzonès-Varoudakis (2004), Nowak-Lehmann (2004), Daraisami (2004) and Hassan and Tufte (1998)], but there are some analyses for imports [see, for example, Kenen and Rodrik (1986), Koray and Lastrapes (1989), Arize and Shwiff (1998) and Pattichis et al. (2004)].

${ }^{3}$ Hu et al. (2004), Couharde and Mazier (2001), Kempa (2000), Heimonen (1999), Sosvilla-Rivero et al. (1999) and Gil-Alana (2004) analyse the evolution of the real exchange rates and the volatility of the European currencies through the different phases of the EMS. Sosvilla-Rivero and Gil-Pareja (2004) study the price convergence of the EU countries. On the positive impact of the coordination of stability policies on Spain see Amuedo-Dorantes and Wheeler (2001).

${ }^{4}$ There is also a widespread debate on this third consideration in recent literature. Carter and Li (2004) analyse the change in trade patterns in OECD countries. Gourlay and Seaton $(2003,2004)$ study, together with the influence of the exchange rate and its variation, the relevance of other non-price factors linked to the characteristics of enterprises. Mahdavi (2002) for US, Martínez-Zarzoso and Suárez-Burguet (2000) for Europe and Gil Pareja (2001) for the European automobile market, also introduce technological progress and productivity as key factors.

${ }^{5}$ A complete overview on structural breaks can be consulted in Maddala and Kim (1998).

${ }^{6}$ See Hylleberg et al. (1990). The results of these tests are not presented due to limitations of space.

${ }^{7}$ Nevertheless, we have also tried with model C (change of level), model C/T (change of level with trend and model $\mathrm{C} / \mathrm{S} / \mathrm{T}$ (change of regime and trend). The results present slight variations to those finally presented.

${ }^{8}$ An application of this technique can be found in Fernández and Sosvilla (2001).

${ }^{9}$ The authors have carried out a thorough review of the literature on Spanish trade functions after the latest works of Escribano (1999) and Montañés and Sanso (2000 y 2002).

${ }^{10}$ For a more detailed analysis of the evolution of exchange rate and prices during this period, see Gadea (2000).

${ }^{11}$ Exports to the EMU represent more than $70 \%$ of the total exports and nearly $90 \%$ of those destined to the developed block. The exchange rate of the euro with respect to other strong currencies on the market the dollar or the yen- it will continue to affect trade.

${ }^{12}$ Between 1985 and 2000 Machinery and Equipment experiences a six percent increase (from $10.74 \%$ to 16.75\%). Martín (1999) and Myro (1999) also point out an increase in the branches of medium technology and the technology-intensive sectors. Furthermore, there has been a considerable effort to adapt product quality to that of the other Community countries. While in 1985 more than half of the intraindustry exports were of lower quality than the imports, in 1995 the proportion had been cut to a little over a third, the increase being especially strong in products of similar quality. See Gordo and Martín (1996).

${ }^{13}$ However, the results obtained both for the domestic and the final demands were worse than those for the GDP. Nevertheless, we do observe, along the lines of other works, an inferior income elasticity when we use demand. Furthermore, we opted for the disaggregation of the GDP into its components, because a better fit was achieved and to avoid capturing with the aggregated GDP more than just a strict income elasticity, for example a possible trend increase in the external openness of the Spanish economy during the period. García and Gordo (1998) also achieved a better fit when they disaggregated the GDP into its 
components, although instability problems in the 1993-1996 period led them finally to select the total GDP. Abbot and Seddighi (1996) for UK imports and Giovannetti (1989) for Italian imports also introduced the components of domestic demand with similar results.

${ }^{14}$ The order of importance of the three components is the expected one and in consonance with other works. Consumption expenditure, apart from the weight of this type of goods in the total imports ( $24 \%$ in 2000), has the strongest participation in the GDP and its series faithfully follows the evolution of the global aggregated GDP. Investment, as well as being a smaller and more divergent part of income, is intimately related with the purchase of machinery and equipment (19\% in 2000). Finally, exports, in spite of also having a reduced participation in the GDP, are linked to the purchase of intermediate products, most of them (57\% in 2000), used as inputs in the production of goods that are later exported.

${ }^{15}$ Matsubayashi and Hamori (2003) find evidence of cointegration with structural change for French and German imports with break points in the early nineties, for France at the beginning of 1993 and for Germany at the end of 1991. Nevertheless, there is no cointegration with structural change in the imports of US, Canada, Japan or UK.

${ }^{16}$ This would indicate that the change in the behaviour of prices should only be introduced in the shortterm dynamic, where they are really significant.

${ }^{17}$ Even higher than 3 if we were to include the aggregated GDP, a higher value than those derived from the other studies, except for that of García and Gordo (1998) who reached a coefficient of up to 3.6.

${ }^{18}$ The analysis of the change in the integration order of the index of the real effective exchange rate, if it is extended until the second quarter of 2003, giving the same break point [1993(I)]. Moreover, these results are confirmed using consumption prices, a measure of competitiveness less partial and so more unfavourable for the Spanish economy than production prices.

${ }^{19}$ Mañez, Rochina and Sanchis (2004) and Moreno (1997) find a significant relationship between some non-price factors and the decision to export. As well as their direct effect, an effect on price elasticity can be seen in which the bigger the product differentiation the smaller the response of exports to variations in relative price. Alonso (1999) notes the relevance of introducing a technological variable that expreses the increase of competitiveness from improvements in quality and, as Balaguer and Cantavella-Jordá (2004), the structural change in the composition of exports. 


\section{REFERENCES}

Abbott, A.J. and Seddighi, H.R. (1996) Aggregate imports and expenditure components in the UK: an empirical analysis, Applied Economics, 28, 1119-1125.

Alonso, J.A. (1999): Growth and the external constraint: lessons from the Spanish case, Applied Economics, 31, 245-253.

Amuedo- Dorantes, C. And Wheeler, M. (2001) An empirical analysis of the European Union's impact on Spanish economic performance, Applied Economics, 33, 10011008.

Aristotelous, K. (2002) The impact of the post-1972 floating exchange-rate regime on US exports, Applied Economics, 34, 1627-1632.

Arize, A.C. and Shwiff, S.S. (1998) Does exchange rate volatility affect import flows in G-7 countires? Evidence from cointegration models, Applied Economics, 30, $1269-1276$.

Bacchetta, P. and van Wincoop, E. (2000) Does exchange rate stability increase trade and welfare?, American Economic Review, 90, 1093-1109.

Bahmani-Oskooee, M. (2001) Nominal and real effective exchange rates of middle eastern countries and their trade performance, Applied Economics, 33, 103-111.

Balaguer, J. and Cantavella-Jordá, M. (2004) Structural change in exports and economic growth: cointegration and causality analysis for Spain (1961-2000), Applied Economics, 36, 473-477.

Banerjee, A., Dolado, J.J. and Mestre, R. (1998) Error-correction mechanism tests for cointegration in a single-equation framework, Journal of time series analysis, vol. 19, n. $3,267-283$.

Baum, C., Caglayan, M. and Ozkan, N. (2004) Nonlinear effects of exchange rate volatility on the volume of bilateral exports, Journal of Applied Econometrics, 19, $1,1-23$.

Buisán, A. and Gordo, E. (1997) El sector exterior en España, Estudios económicos, n. 60, Banco de España.

Carter, C.A. and Li, X. (2004) Changing trade patterns in major OECD countries, Applied Economics, 36, 1501-1511.

Couharde, C. and Mazier, J. (2001) The equilibrium exchange rates of European currencies and the transition to euro, Applied Economics, 33, 1795-1801.

Daraisimi, A. (2004) Export growth slowdown and currency crisis: the Malaysian experience, Applied Economics, 36, 1947-1957.

De Grauwe, P. (1988) Exchange rate variability and the slowdown in growth of international trade, IMF Staff Papers, 35. 63-84.

Dickey, D.A and Fuller, W.A. (1981) Likelihood ratio statistics for autoregressive time series with a unit root, Econometrica 49, 1057-1072.

Doyle, E. (2001) Exchange rate volatility and Irish-UK trade, Applied Economics, 33, 249-265. 
Engle, R. and Granger, C. (1987) Co-integration and error correction: representation, estimation and testing, Econometrica 55, 251-276.

Engle, R. And Granger, C. (1990) Cointegración y corrección de error: representación, estimación y contrastes, Cuadernos económicos de Información Comercial Española 44, 53-82.

Escribano, A. (1999) Predicción y análisis de funciones de exportación e importación en España, Investigaciones Económicas, vol. XXIII (1), 55-94.

Fernández Serrano, J.L. and Peruga, R. (1999) Un contraste ADF secuencial para la detección de cambios en el orden de integración, Working Paper 6/99. Universidad Europea-CEES.

Fernández Serrano, J.L. and Peruga, R. (2005) Un contraste ADF secuencial para la detección de cambios en el orden de integración, Revista de Economía Aplicada, 37.

Fernández Serrano, J.L. and Sosvilla Rivero, S. (2001) Modelling evolving long-run relationships: the linkages between stock markets in Asia, Japan and the World Economy 13, 145-160.

Fuller, W.A. (1976) Introduction to statistical time series, John Wiley and Sons, Nueva York.

Gadea Rivas, M.D. (2000) La peseta en la cultura de la estabilidad, 1989-1999, in García Delgado, J.L. y Serrano Sanz, J.M. (dirs.) Del real al euro. Una historia de la peseta, Colección Estudios Económicos la Caixa, n. 21, 169-190.

García, C. and Gordo, E. (1998) Funciones trimestrales de exportación e importación para la economía española, Documento de trabajo n. 22, Servicio de Estudios Banco de España.

Gil Pareja, S. (2001): Pricing to market in European automobile exports to OECD countries: a panel data approach, Applied Economics, 33, 1845-1856.

Gil-Alana, L.A. (2004): The dynamics of the real exchange rates in Europe: a comparative study across countries using fractional integration, Applied Economics Letters, 11, 429-432.

Giovannetti, G. (1989) Aggregate imports and expenditure components in the Italia: an econometric analysis, Applied Economics, 21, 957-971.

Gordo, E. and Martín, C. (1996) Integración económica, comercio intraindustrial y costes de ajuste, Revista de Economía Aplicada, vol. IV, n. 12, 151-164.

Gourlay, A. and Seaton, J. (2003) Export intensity in UK firms, Applied Economics Letters, 10, 471-477.

Gourlay, A. and Seaton, J. (2004) Explaining the decision to export: evidence from UK firms, Applied Economics Letters, 11, 153-158.

Gregory, A.W. and Hansen, B.E. (1996a) Residual-based tests for cointegration in models with regime shifts, Journal of Econometrics, n. 70, 99-126.

Gregory, A.W. and Hansen, B.E. (1996b) Tests for cointegration in models with regime and trend shifts, Oxford Bulletin of Economics and Statistics, vol. 58, n. 3, 555560. 
Grier, K.B. and Smallwood, A. (2003) Real exchange rate uncertainty and export performance: evidence from 18 countries, University of Oklahoma, Norman OK 73071.

Hansen, B.E. (1992) Tests for parameter instability in regressions with I(1) processes, Journal of Business \& Economic Statistics, vol. 10, n. 3, 321-335.

Hassan, M.K. and Tufte, D.R. (1998) Exchange rate volatility and aggregate export growth in Bangladesh, Applied Economics, 30, 189-201.

Heimonen, K. (1999): Stationary of the European real exchange rates - evidence from panel data, Applied Economics, 31, 673-677.

Hu, M.Y., Jiang, C.X. and Tsoukalas, C. (2004) The volatility impact of the European monetary system on member and non-member currencies, Aggregate imports and expenditure components in the UK: an empirical analysis, Applied Financial Economics, 14, 313-325.

Hylleberg, S., Engle, R., Granger, C. and Yoo, B. (1990) Seasonal integration and cointegration, Journal of Econometrics 44, 215-238.

In, F. and Menon, J., (1996) The long-run relationship between the ral exchang rate and terms of trade in OECD countries, Applied Economics, 28, 1075-1080.

Johansen, S. (1988) Statistical analysis of cointegration vectors, Journal of Economic Dynamics and Control, vol. 12, 231-254.

Johansen, S. and Juselius, K. (1990) Maximum likelihood estimation and inference on cointegration with applications to the demand for money, Oxford Bulletin of Economics and Statistics, vol. 52, 169-210.

Kempa, B. (2000): Excess volatility of real exchange rates in the EMS: some evidence from structural VARs, Applied Economics, 32, 73-79.

Kenen, P.T. and Rodrik, D. (1986) Measuring and analysing the effects of short-term volatility in real exchange rates, Review of Economics and Statistics, 68, 311-315.

Koray, F. and Lastrapes, W.D. (1989) Real exchange rate volatility and U.S. bilateral trade: a VAR approach, Review of Economics and Statistics, 71, 708-712.

Lane, P.R. and Milesi-Ferretti, G.M. (2002a) External wealth, the trade balance, and the real exchange rate, European Economic Review, 46, 1049-1071.

Maddala. G.S. and Kim, I. (1998) Unit Roots, Cointegration and Structural Change, Cambridge University Press, Cambridge, United Kingdom.

Mahdavi, S. (2002) The response of the US export prices to changes in the dollar's effective exchange rate: further evidence from industry level data, Applied Economics, 34, 2115-2125.

Mañez, J.A., Rochina, M.E. and Sanchis, J.A. (2004) The decision to export: a panel data analysis for Spanish manufacturing, Applied Economics Letters, 11, 669-673.

Martín, C. (1999) La integración de España en la Unión Europea, in García Delgado, J.L. (dir.) Lecciones de economía española, Civitas, 435-464.

Martínez-Zarzoso, I. and Suárez-Burguet, C. (2000) The determinants of trade performance: influence of R\&D on export flows, Applied Economics, 32, 19391946. 
Matsubayasi, Y. and Hamori, S. (2003) Some international evidence on the stability of aggregate import demand function, Applied Economics, 35, 1497-1504.

Mauleón, I. and Sastre, L. (1996) El saldo comercial en el bienio 1993-94: ¿Asistimos a un cambio estructural en el comportamiento de nuestra balanza comercial?, Información Comercial Española, Revista de Economía 752, 99-103.

Montañés, A. and Sanso, M. (2000) Análisis estructural de las importaciones y exportaciones de bienes de la economía española, Revista de Economía Aplicada, vol. VIII, n. 24, 5-37.

Montañés, A. and Sanso, M. (2002) Cointegration, error correction mechanism and trade liberalization: the case of the Spanish imports of manufactures, Applied Economics 34, 231-240.

Moreno, L. (1997) The determinants of Spanish industrial exports to the European Union, Applied Economics, 29, 723-732.

Morgenroth, E.L.W. (2000) Exchange rates and trade: the case of Irish exports to Britain, Applied Economics, 32, 107-110.

Myro, R. (1999) España en la Unión Europea: etapas y efectos de la integración, in García Delgado, J.L. (dir.) España, Economía: Ante el siglo XXI, Espasa, Madrid, 241-270.

Nabli, M.K. and Véganzonès-Varoudakis, M. (2004) How does exchange rate policy affect manufactured exports in MENA countries? Applied Economics, 36, 22092219.

Nachane, D.M. and Prasad, P.R. (1998) India's trade balance in the 1980s- an econometric analysis, Applied Economics, 30, 761-774.

$\mathrm{Ng}$, S. and Perron, P. (1995) Unit root tests in ARMA models with data dependent methods for the truncation lag, Journal of the American Statistical Association 90, 268-281.

Nowak-Lehmann, F. (2004) Different approaches of modelling reaction lags: how do Chilean manufacturing exports to movements of the real exchange rate?, Applied Economics, 36, 1547-1560.

Park, J. (1992) Canonical cointegration regression, Econometrica 60, 119-144.

Pattichis, C., Cheong, C., Mehari, T. and Williams, L.W. (2004) Exchange rate uncertainty, UK trade and the euro, Applied Financial Economics, 14, 885-893.

Perron, P. (1989) The great crash, the oil price shock, and the unit root hypothesis, Econometrica 57, 1361-1401.

Perron, P. (1994) Further evidence on breaking trend functions in macroeconomic variables, Working Paper, n. 2594, C.R.D.E., Université de Montreal, Canada.

Perron, P. and Vogelsang, T.J. (1992) Nonstationarity and level shifts with an application to purchasing power parity, Journal of Business and Economic Statistics 10, 301-320.

Phillips, P. and Hansen, B. (1990) Statistical inference in instrumental variables regression with I(1) processes, Review of Economic Studies 57, 99-125.

Sosvilla- Rivero, S. and Gil- Pareja, S. (2004): Price convergence in the European Union, Applied Economics Letters, 11, 39-47. 
Sosvilla- Rivero, S., Fernández-Rodríguez, F. and Bajo- Rubio, O. (1999): Exchange rate volatility in the EMS before and after the fall, Applied Economics Letters, 6, 717-722.

Vogelsang, T.J. and Perron, P. (1998) Additional test for a unit root allowing for a break in the trend function at an unknown time, International Economic Review, vol. 39, n. $4,1073-1100$.

Zivot, E. and Andrews, D.W.K. (1992) Further evidence on the great crash, the oil-price shock, and the unit-root hypothesis, Journal of Business and Economic Statistics $10,251-270$. 